\title{
EFFECTS OF PISTACIA ATLANTICA RESIN OIL ON THE LEVEL OF VEGF, HYDROXYPROLINE, ANTIOXIDANT AND WOUND HEALING ACTIVITY IN STZ-INDUCED DIABETIC RATS
}

\author{
B. SHAHOUZEHI , M. SHABANI', N. SHAHROKHI ${ }^{3}$, \\ S. SADEGHIYAN ${ }^{4}$, Y. MASOUMI-ARDAKANI ${ }^{5 *}$ \\ ${ }^{1}$ Cardiology Research Center, Institute of Basic and Clinical Physiology \\ Sciences, Kerman University of Medical Sciences, Kerman, Iran; \\ e-mail: bshahouzehi@yahoo.com; \\ ${ }^{2}$ Neuroscience Research Center, Institute of Neuropharmacology, \\ Kerman University of Medical Sciences, Kerman, Iran; \\ ${ }^{3}$ Department of Physiology, Afzalipour School of Medicine \& Physiology Research \\ Center, Kerman University of Medical Sciences, Kerman, Iran; \\ ${ }^{4}$ Neuroscience Research Center, Institute of Neuropharmacology, \\ Kerman University of Medical Sciences, Kerman, Iran; \\ ${ }^{5}$ Physiology Research Center, Institute of Basic and Clinical Physiology \\ Sciences, Kerman University of Medical Sciences, Kerman, Iran; \\ e-mail:ymab125@gmail.com
}

Diabetes mellitus is a chronic metabolic disorder which is followed by many complications. One of these problems following diabetes is diabetic ulcers and 2.5\% of diabetic patients develop foot ulcer annually. Natural resources are useful stock for finding traditional treatment. Studies which examined Pistacia atlantica properties showed that it has some beneficial effects including: antimicrobial, antifungal, antioxidant and wound healing. Yet, Pistacia atlantica resin oil effects on diabetic wound have not been examined. Therefore, we evaluate Pistacia atlantica resin oil antioxidant and wound healing activity. Sprague-Dawley male rats were entered to the study and randomly grouped $(n=10)$ as follows: group 1 - control group - burnt rats which received neither STZ nor Pistacia atlantica resin oil; group 2 -diabetic burnt rats; group 3 -diabetic burnt rats which received $250 \mu \mathrm{l} /$ day Pistacia atlantica resin oil topically as an ointment for two weeks. At the end of the study antioxidant status, Vascular Endothelial Growth Factor (VEGF) and hydroxyproline contents were examined in the wound area. Our results showed that Pistacia atlantica resin oil has remarkable antioxidant activity in STZ-induced diabetic rats. Also, it promoted VEGF and hydroxyproline contents in the wound area which showed that it increases angiogenesis and collagen turnover in the diabetic wound. We concluded that Pistacia atlantica resin oil can be considered as a new therapeutic agent in diabetic wound healing, and also it is safe, available and cheap treatment of other wounds and skin injuries.

Key word s: Pistacia atlantica resin oil, diabetic wound, VEGF, hydroxyproline, antioxidants.

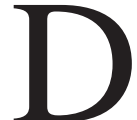
iabetes mellitus is a common metabolic disorder with high prevalence worldwide. Adult diabetes estimation in 2014 is about 422 million [1]. It has been predicted that this number will rise to a number about 592 million in 2035 [2]. Diabetes is followed by kidney failure, blindness and non-traumatic lower-limb amputations and also diabetes is a major cause of heart diseases [1]. About
$2.5 \%$ of diabetic patients develop foot ulcer annually and on the other hands, the treatment of diabetic ulcers is complex [3, 4]. Mortality and morbidity rates of diabetes are associated with impaired wound healing and foot ulcer [1]. Many available synthetic drugs for the treatment of wound are expensive and also can cause allergy or resistance, and then the finding of an alternative new drug is a necessity.

(C) 2018 Shahouzehi B. et al. This is an open-access article distributed under the terms of the Creative Commons Attribution License, which permits unrestricted use, distribution, and reproduction in any medium, provided the original author and source are credited. 
Natural resources are useful widespread stock for finding new treatment and the importance of natural resources for drug development has been shown by ethnobotanical and ethnopharmacological research which lead to a discovery of therapeutic properties which provided by plants derived components [5]. The genus Pistacia belongs to Anacardiaceae family which has fifteen species and three of them are grown in Iran [5-7]. Pistachio (Pistacia atlantica) is a plant that distributed in the area such as Mediterranean, Algeria and Iran [7]. Pistacia atlantica's oil, kernel oil and resin oil contains many components and the chemical composition have been described previously [8-10]. Its resin traditionally used as chewing gum, mouth freshener and anti-peptic treatment $[9,10]$. There are different studies which have examined other properties of Pistacia atlantica oil and they have reported antimicrobial, antifungal, antiparasite, antioxidant and wound healing activity of Pistacia atlantica oil [11-18]. Pistacia atlantica has been used traditionally for the treatment of hepatic and digestive diseases and also heart and respiratory system disorders [6]. Diabetes is a chronic disease and also there is a remarkable chance of ROS (Reactive Oxygen Species) production which leads to reduced antioxidant defense capacity. This can deteriorate diabetic patient condition and also affect other complications of diabetes such as wound healing, renal function and vision [16]. Some studies have reported that Pistacia atlantica oil has antioxidant and free radical scavenging activity and therefore it may have wound healing activity [5, 19-21]. But these studies were performed in non-diabetic condition; hence we evaluated these properties in a diabetic rat model.

Vascular Endothelial Growth Factor (VEGF) has an important role in tissue repair and wound healing. VEGF causes migration of endothelial and inflammatory cells in a wounded area [22]. Also, it has been described that extracellular matrix protein, collagen, has a pivotal role in wound healing [23].

There are some studies about Pistacia atlantica oil wound healing activity [5, 17, 18], but there was no study about Pistacia atlantica resin oil wound healing activity in diabetic models as we designed. Then we conduct this study to evaluate Pistacia atlantica resin oil effects on wound healing and contraction, antioxidant, VEGF and hydroxyproline levels in experimentally wounded and STZ-induced diabetic rat.

\section{Materials and Methods}

Animals. Thirty Male Sprague-Dawley rats weighing $210 \pm 10$ g were obtained from the animal care center of Kerman Neuroscience Research Center. The animals were kept in controlled condition at $25 \pm 1^{\circ} \mathrm{C}$ and $12 \mathrm{~h} \mathrm{light-dark} \mathrm{cycle,} 7$ days for acclimatization. Our study was approved by the ethics committee of Kerman University of Medical Sciences, Kerman, Iran.

Plant oil. The Pistacia atlantica resin oil which we have used in our study was prepared by HakimTehrani Co. Kerman, Iran. Full compositions of Pistacia atlantica resin oil have been reported previously then we referred to these studies which reported its constituents [9, 10].

Diabetes induction and Burn injury. Diabetes was induced by single intraperitoneal injection of 50 mg/kg STZ (Sigma, St. Luis, MO, USA). Three days after STZ injection, the animals were fasted $12 \mathrm{~h}$ overnight and then the blood glucose was measured and rats with blood glucose higher than $250 \mathrm{mg} / \mathrm{dl}$ were entered to the study [24]. Three weeks after diabetes induction, the animals were anesthetized with i.p. injection of ketamine and xylazine ( 50 \& $5 \mathrm{mg} / \mathrm{kg}$, respectively). The dorsal side of the animals was shaved and cleaned by ethanol $70 \%$ and then induction of burn damage was conducted by an aluminum plaque $(3 \times 2.5 \mathrm{~cm})$ heated to $100{ }^{\circ} \mathrm{C}$ on the skin of rats for $10-12 \mathrm{sec}$ to create a deep dermal burn wound [12, 14].

Study procedure. Duration of study was 14 days, and animals were divided into three groups $(n=10)$ randomly as follow: group 1 - control group which just burnt and received neither STZ nor Pistacia atlantica resin oil, group 2 - diabetic burnt rats, group 3 - diabetic burnt rats which received $250 \mu \mathrm{l} /$ day Pistacia atlantica resin oil topically [14, 25].

At the end of the study, animals were deeply anesthetized by ether and sacrificed, then the wound area of the skin $(1 \times 1 \mathrm{~cm})$ was excised and then the skin samples were homogenized in order to assay Superoxide dismutase (SOD), Glutathione Peroxidase (GPX), Malondialdehyde (MDA), VEGF and Hydroxyproline in the supernatant.

Wound size estimation. Wound size was measured by paper ruler at the end of the study.

Assessments of VEGF, Hydroxyproline, SOD, $G P X \& M D A$. Evaluation of these parameters except MDA were conducted by specific kits (Hydroxyproline ELISA assay kit E0511Ra, Crystal Day Biotech 
inc.; VEGF ELISA assay kit E0659Ra, Crystal Day Biotech inc.; SOD \& GPX assay kits from RANDOX inc.). MDA level was measured at $532 \mathrm{~nm}$ by thiobarbituric acid (TBA) method.

\section{Results and Discussion}

Our results showed that Pistacia atlantica resin oil has remarkable wound healing activity. It significantly reduced wound size compared to control and diabetic control group, $P<0.001$ (Table). As demonstrated in Fig. 1, Pistacia atlantica resin oil significantly reduced MDA levels compared to diabetic control group and MDA levels reached to about control levels. Also, Pistacia atlantica resin oil significantly increased antioxidant defense compared to diabetic control (Fig. 2 and 3) and increased VEGF and hydroxyproline indicating its beneficial effects in diabetic wound healing (Fig. 4 and 5).

Statistical analysis. The data were reported as Mean \pm SEM. Data analysis was performed by OneWay ANOVA, and in order to a pairwise comparison between groups, we used Tukey's Test.

Pistacia atlantica oil properties have been studied previously and are including; antiparasite, antimicrobial, antifungal, antipeptic, wound healing and antioxidant activity [5-7, 12-15, 18]. There is no mechanistic and worthy proof about wound healing activity of Pistacia atlantica resin oil which traditionally is used in southeastern parts of Iran for wound healing [18]. Hamidi and colleagues have shown that Pistacia atlantica oil wound healing activity was remarkable from day 10 until end of their study (day 21). They have shown that Pistacia atlantica increased antioxidant capacity in the serum of treated animals [12]. Their serum data are along with our data which obtained from the wounded skin of diabetic rats and both studies are emphasizing on an antioxidant activity of Pistacia atlantica oil. Compared to Hamadi and colleagues study we also targeted diabetic wound treatment and also assessed VEGF and hydroxyproline contents in wound area to have a better judgment about mechanism of the Pistacia atlantica resin oil effect. Farahpour et al, have also studied Pistacia atlantica's oil wound healing properties in a rat model and their results supported our findings on Pistacia atlantica resin oil beneficial effects on wound healing in diabetic rats [11]. Previous studies revealed the chemical composition of Pistacia atlantica resin oil which includes $\alpha$-pinene, camphene, $\beta$-myrcene and limonene as main components [8-10, 13]. $\alpha$-Pinene was reported as major constituents of Pistacia atlantica resin oil and has very low toxicity [10]. Rezaie and coworkers have demonstrated that Pistacia atlantica hull oil has free radical scavenging activity which was comparable to $\alpha$-tocopherol in vitro, and this confirmed that Pistacia atlantica acts against oxidative stress [26]. Finally, consistent with these studies we showed that Pistacia atlantica resin oil has potent antioxidant activity and also we showed that antioxidant capacity of Pistacia atlantica resin oil in diabetic model is still present which was not reported before. These findings also indicate that Pistacia atlantica resin oil is very strong antioxidant ointment which fights against oxidative states that present in diabetes condition.

In another study which described Pistacia atlantica oil effect on diabetes, they found that it has anti-diabetic action [27]. Also Hashemnia M. et al. (2015) showed that Pistacia atlantica oil alcoholic extract reduced blood glucose in STZ-induced diabetic rats, however, they did not clarify the mechanism of anti-diabetic action of Pistacia atlantica oil, but based on other studies they assumed that this effect may contribute to plants potential action through many ways such as reduced hepatic glucose production, elevation of glucose utilization and increase or facilitate the insulin actions in target tissues [24].

Glucose level and wound contraction size in Control, Diabetic and diabetic P. atlantica oil treated groups. Glucose levels were measured at day 14 after $12 \mathrm{~h}$ fasting overnight. All data are presented in Mean \pm SEM $(n=10)$

\begin{tabular}{l|c|c}
\hline \multicolumn{1}{c|}{ Groups } & Glucose, $\mathrm{mg} / \mathrm{dl}$ & Wound size, $\mathrm{mm}^{2}$ \\
\hline Control & $108.00 \pm 2.07$ & $2.38 \pm 0.089$ \\
Diabetic control & $361.74 \pm 9.93^{\mathrm{a}}$ & $5.26 \pm 0.07^{8 \mathrm{a}}$ \\
Diabetic + P. atlantica oil & $371.61 \pm 11.86$ & $0.910 \pm 0.048^{\mathrm{b}}$ \\
\hline
\end{tabular}

a Significant compared to control group. ${ }^{\mathrm{b}}$ Significant compared to diabetic control group. $P<0.05$ was considered as statistically significant 


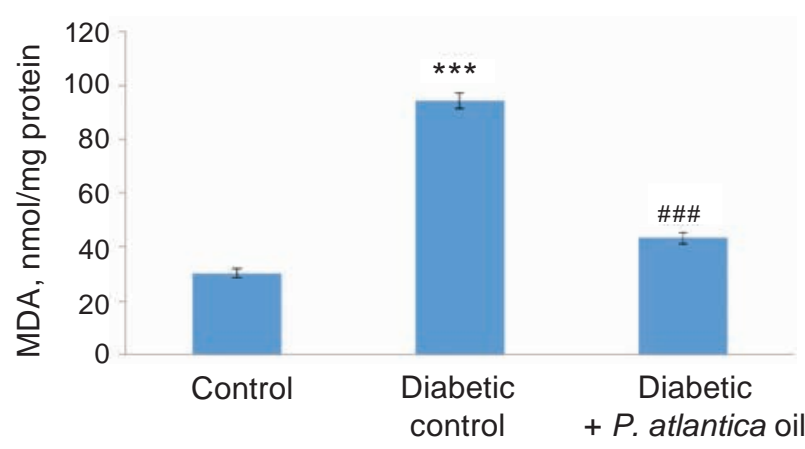

Fig. 1. Effect of STZ-induced diabetes and Pistacia atlantica resin oil on the MDA level in male rats $(n=10)$. Control group did not received any treatment, Diabetic control group received single STZ i.p injection $(50 \mathrm{mg} / \mathrm{kg})$, and Diabetic + $P$. atlantica resin oil received single STZ i.p injection plus $P$. atlantica resin oil topically. Data were expressed as mean $\pm S E M$. *** $P<0.001$ vs control group; ${ }^{\#} P<0.001$ vs diabetic control group

But these anti-diabetic actions of Pistacia atlantica are not concrete and needs more evaluations to define its probable mechanism in diabetes.

We also measured VEGF and hydroxyproline. Nissen and colleagues have suggested that VEGF plays an important role in angiogenesis [22]. Galiano R. D. et al. [28] have shown that topical VEGF has beneficial effects on wound healing through many actions including mobilizing cells derived from bone marrow to wound area in order to facili-

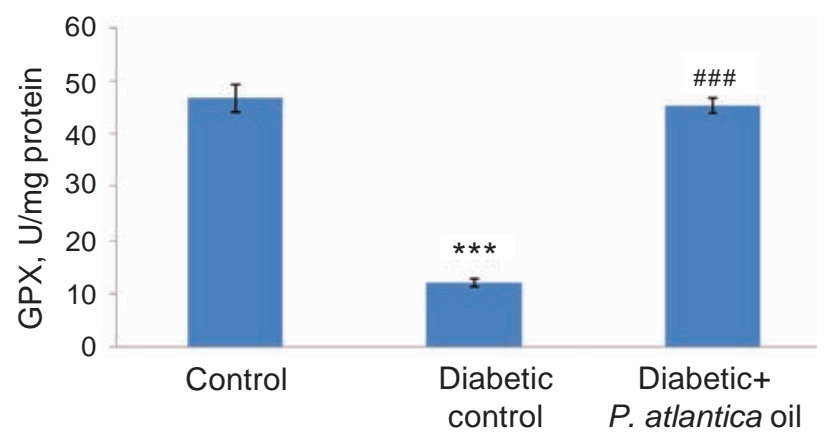

Fig. 3. Effect of STZ-induced diabetes and Pistacia atlantica resin oil on the GPX level in male rats $(n=10)$. Control group did not received any treatment, Diabetic control group received single STZ i.p injection $(50 \mathrm{mg} / \mathrm{kg})$, and Diabetic $+P$. atlantica resin oil received single STZ i.p injection plus $P$. atlantica resin oil topically. Data were expressed as mean \pm SEM. ${ }^{* * *} P<0.001$ vs control group; \#\#\# $P<0.001$ vs diabetic control group

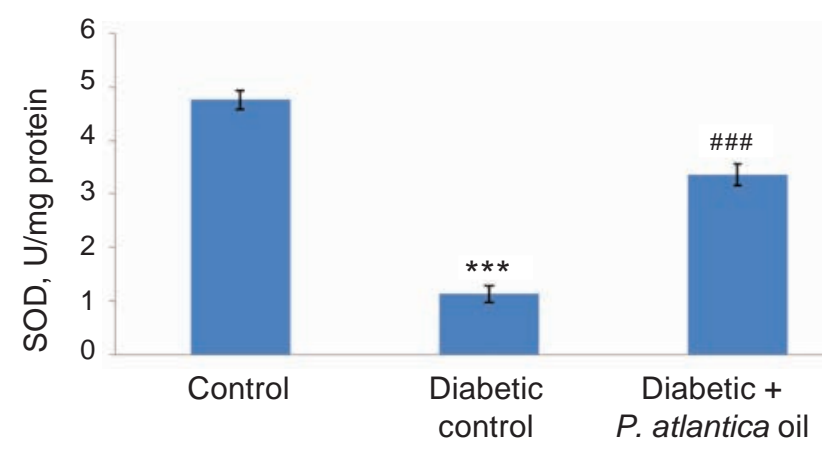

Fig. 2. Effect of STZ-induced diabetes and Pistacia atlantica resin oil on the SOD level in male rats $(n=10)$. Control group did not received any treatment, Diabetic control group received single STZ i.p injection $(50 \mathrm{mg} / \mathrm{kg})$, and Diabetic + $P$. atlantica resin oil received single STZ i.p injection plus $P$. atlantica resin oil topically. Data were expressed as mean $\pm S E M$. ${ }^{* * *} P<0.001$ vs control group; ${ }^{\# \#} P<0.001$ vs diabetic control group

tate wound repair. They conclude that VEGF can be considered as a therapeutic agent for treatment of diabetic ulcers. Therefore, VEGF and hydroxyproline can be considered as angiogenesis and wound healing rate marker respectively in damaged areas [22]. Farahpour M. R. et al. (2015) have shown that different doses of Pistacia atlantica increase hydroxyproline content in the wound which leads to neovascularization [11]. Haghdoost and colleagues showed that there is a dose-dependent correlation

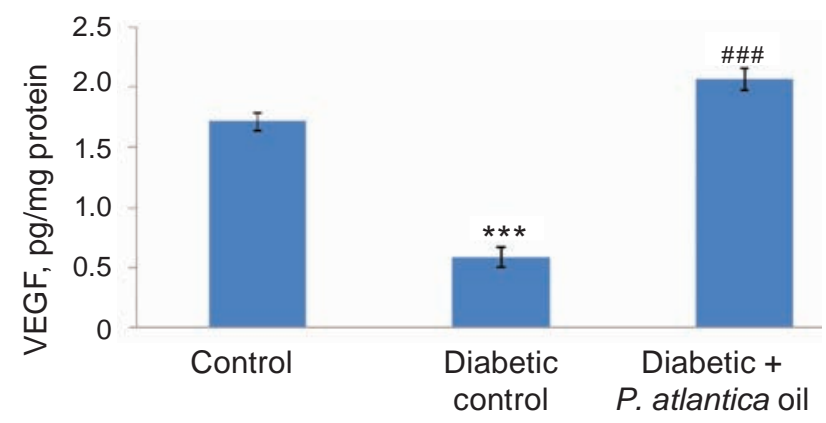

Fig. 4. Effect of STZ-induced diabetes and Pistacia atlantica resin oil on the VEGF level in male rats $(n=10)$. Control group did not received any treatment, Diabetic control group received single STZ i.p injection $(50 \mathrm{mg} / \mathrm{kg})$, and Diabetic + P. atlantica resin oil received single STZ i.p injection plus $P$. atlantica resin oil topically. Data were expressed as mean \pm SEM. ${ }^{* * *} P<0.001$ vs control group; \#\#\# $P<0.001$ vs diabetic control group 


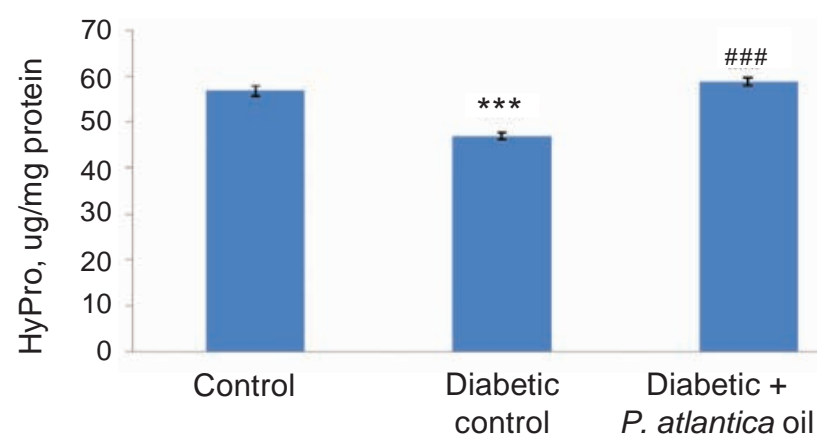

Fig. 5. Effect of STZ-induced diabetes and Pistacia atlantica resin oil on the HyPro level in male rats $(n=10)$. Control group did not received any treatment, Diabetic control group received single STZ i.p injection $(50 \mathrm{mg} / \mathrm{kg})$, and Diabetic $+P$. atlantica resin oil received single STZ i.p injection plus $P$. atlantica resin oil topically. Data were expressed as mean \pm SEM. ${ }^{* * *} P<0.001$ vs control group; \#\#\# $P<0.001$ vs diabetic control group

between Pistacia atlantica and VEGF levels [14]. We also showed that Pistacia atlantica resin oil promoted VEGF levels which can result in angiogenesis and play a pivotal role in wound healing.

Hydroxyproline is one of the main components of collagen which is an extracellular matrix protein. Hydroxyproline levels are a good marker of collagen turnover and content [23]. Ilango K. and Chitra V. (2010) [29] showed that Limonia Acidissima Linn fruit extract increased hydroxyproline levels and collagen which was confirmed by their pathology reports. Here we showed that Pistacia atlantica resin oil also increased collagen contents in wound tissue samples and is useful for wound repair and healing.

Plants resources are very good and available stock for finding new therapeutic agents. Interestingly, we found that Pistacia atlantica resin oil has remarkable antioxidant activity and also increased VEGF which helps wound healing rate by angiogenesis. Also, Pistacia atlantica resin oil active ingredient is $\alpha$-pinene, which as reported, has low toxicity and considered as an active component which is responsible for some observed effects. Therefore, Pistacia atlantica resin oil can be evaluated as a new agent in diabetic wound healing and also can be used for other wounds and injuries treatment. Finally, the question remains, whether these beneficial observations are the result of the effects of Pistacia atlantica resin oil on biochemical parameters in wound healing, or whether these differences in biochemical parameters appeared secondary to better healing. It seems that this oil positively affects biochemical parameter and gradually heals the wound area in the diabetic model. Our findings support the hypothesis that Pistacia atlantica resin oil improves blood flow and vascularization by elevation of VEGF levels and reduces harmful effects of diabetic oxidative status, as well as burn damage in the wound area.

Acknowledgement. This research was financially supported by Research Council of Kerman University of Medical Sciences

Conflict of interest. The authors declare that there are no conflicts of interest. 
ВПЛИв ОЛІї ЗІ СМОЛИ

Pistacia atlantica HA PIBEHЬ

VEGF, ГІДРОКСИПРОЛІНУ,

АНТИОКСИДАНТНУ I

РАНОЗАГОЮВАЛЬНУ

АКТИВНІСТЬ У ЩУРІВ ЗІ

СТРЕПТОЗОТОЦИНІНДУКО-

ВАНИМ ДІАБЕТОМ

B. Shahouzehi', M. Shabani', N. Shahrokhi ${ }^{3}$,

S. Sadeghiyan ${ }^{4}$, Y. Masoumi-Ardakani ${ }^{5 *}$

${ }^{1}$ Cardiology Research Center, Institute of Basic and Clinical Physiology Sciences, Kerman

University of Medical Sciences, Kerman, Iran; e-mail: bshahouzehi@yahoo.com;

${ }^{2}$ Neuroscience Research Center, Institute of

Neuropharmacology, Kerman University

of Medical Sciences, Kerman, Iran;

${ }^{3}$ Department of Physiology, Afzalipour School of

Medicine \& Physiology Research Center, Kerman

University of Medical Sciences, Kerman, Iran;

${ }^{4}$ Neuroscience Research Center, Institute of

Neuropharmacology, Kerman University of Medical Sciences, Kerman, Iran;

${ }^{5}$ Physiology Research Center, Institute of Basic and Clinical Physiology Sciences, Kerman

University of Medical Sciences, Kerman, Iran; *e-mail: ymab125@gmail.com

Цукровий діабет належить до хронічних метаболічних захворювань, які супроводжуються численними ускладненнями. Одним із таких ускладнень $є$ діабетична виразка стопи, яка розвивається у $2,5 \%$ пацієнтів із діабетом. Природні ресурси - корисне джерело для пошуку ефективних засобів традиційного лікування діабету. Дослідження з вивчення властивостей Pistacia atlantica показали, що ця рослина має протимікробну, протигрибкову, антиоксидантну і ранозагоювальну дію. В роботі вивчали антиоксидантну і ранозагоювальну активність масла 3 Pistacia atlantica на діабетичну рану щурів. Самців щурів лінії Sprague-Dawley було випадковим чином розділено на три групи: група 1 (контроль) - тварини з опіком не отримували ні стрептозотоцин, ні масло зі смоли Pistacia atlantica; група 2 - тварини 3 опіком і стрептозотоциніндукованим діабетом; група 3 тварини $з$ опіком і стрептозотоциніндукованим діабетом, які отримували 250 мкл/день олії зі смоли Pistacia atlantica у вигляді мазі, місцево, протягом двох тижнів. Досліджували антиоксидантний статус, рівень судинно- го ендотеліального фактора росту (VEGF) i гідроксипроліну в області рани. Результати показали, що масло зі смоли Pistacia atlantica мало високу антиоксидантну активність у щурів зі стрептозотоциніндукованим діабетом. Крім того, спостерігали збільшення вмісту VEGF i гідроксипроліну в області рани, що вказувало на активізацію ангіогенезу і синтез колагену в діабетичній рані. Зроблено висновок, що масло зі смоли Pistacia atlantica можна розглядати як новий терапевтичний агент для загоєння діабетичної рани, а також як безпечний, доступний і дешевий засіб за лікування різних ран і пошкоджень шкіри.

К л ючов і слов а: масло зі смоли Pistacia atlantica, діабетична рана, судинний ендотеліальний фактор росту (VEGF), гідроксипролін, антиоксиданти.

\section{ВЛИЯНИЕ МАСЛА ИЗ СМОЛЫ Pistacia atlantica НА УРОВЕНЬ VEGF, ГИДРОКСИПРОЛИНА, АНТИОКСИДАНТНУЮ И РАНОЗАЖИВЛЯЮЩУЮ АКТИВНОСТЬ У КРЫС СО СТРЕПТОЗОТОЦИНИНДУЦИ- РОВАННЫМ ДИАБЕТОМ}

B. Shahouzehi', M. Shabani², N. Shahrokhi', S. Sadeghiyan ${ }^{4}$, Y. Masoumi-Ardakani ${ }^{5 *}$

${ }^{1}$ Cardiology Research Center, Institute of Basic and Clinical Physiology Sciences, Kerman

University of Medical Sciences, Kerman, Iran; e-mail: bshahouzehi@yahoo.com;

${ }^{2}$ Neuroscience Research Center, Institute of Neuropharmacology, Kerman University of Medical Sciences, Kerman, Iran;

${ }^{3}$ Department of Physiology, Afzalipour School of Medicine \& Physiology Research Center, Kerman

University of Medical Sciences, Kerman, Iran;

${ }^{4}$ Neuroscience Research Center, Institute of Neuropharmacology, Kerman University of Medical Sciences, Kerman, Iran;

${ }^{5}$ Physiology Research Center, Institute of Basic and Clinical Physiology Sciences, Kerman

University of Medical Sciences, Kerman, Iran; e-mail: ymab125@gmail.com

Сахарный диабет относится к хроническим метаболическим заболеваниям, которые сопровождаются многочисленными осложнениями. Одним из таких осложнений является 
диабетическая язва стопы, которая развивается у 2,5\% пациентов с диабетом. Природные ресурсы - полезный источник для поиска эффективных средств традиционного лечения диабета. Исследования по изучению свойств Pistacia atlantica показали, что растение обладает противомикробным, противогрибковым, антиоксидантным и ранозаживляющим действием. В работе изучали антиоксидантную и ранозаживляющую активность масла из Pistacia atlantica на диабетическую рану крыс. Самцы крыс линии Sprague-Dawley были случайным образом разделены на три группы: группа 1 (контроль) животные с ожогом не получали ни стрептозотоцин, ни масло из смолы Pistacia atlantica; группа 2 - животные с ожогом и стрептозотоцининдуцированным диабетом; группа 3 - животные с ожогом и стрептозотоцининдуцированным диабетом, получавшие 250 мкл/день масла из смолы Pistacia atlantica в виде мази, местно, в течение двух недель. Исследовали антиоксидантный статус, уровень сосудистого эндотелиального фактора роста (VEGF) и гидроксипролина в области раны. Результаты показали, что масло из смолы Pistacia atlantica обладало высокой антиоксидантной активностью у крыс со стрептозотоцининдуцированным диабетом. Кроме того, наблюдали увеличение содержания VEGF и гидроксипролина в области раны, что указывало на активизацию ангиогенеза и синтез коллагена в диабетической ране. Сделан вывод, что масло из смолы Pistacia atlantica можно рассматривать как новый терапевтический агент для заживления диабетической раны, а также как безопасное, доступное и дешевое средство при лечении различных ран и повреждений кожи.

Ключе вы е слов а: масло из смолы Pistacia atlantica, диабетическая рана, сосудистый эндотелиальный фактор роста (VEGF), гидроксипролин, антиоксиданты.

\section{References}

1. Organization WH. Global report on diabetes, World Health Organization. 2016.

2. Guariguata L, Whiting DR, Hambleton I, Beagley J, Linnenkamp U, Shaw JE. Global estimates of diabetes prevalence for 2013 and projections for 2035. Diabetes Res Clin Pract. 2014; 103(2): 137-149.
3. Abetz L, Sutton M, Brady L, McNulty P, Gagnon DD. The Diabetic Foot Ulcer Scale (DFS): a quality of life instrument for use in clinical trials. Pract Diabetes Int. 2002; 19(6): 167-175.

4. Sheehan P, Jones P, Caselli A, Giurini JM, Veves A. Percent change in wound area of diabetic foot ulcers over a 4 -week period is a robust predictor of complete healing in a 12week prospective trial. Diabetes Care. 2003; 26(6): 1879-1882.

5. Bahmani M, Saki K, Asadbeygi M, Adineh A, Saberianpour S, Rafieian-Kopaei M, Bahmani F, Bahmani E. The effects of nutritional and medicinal mastic herb (Pistacia atlantica). J Chem Pharm Res. 2015; 7(1): 646-653.

6. Bozorgi M, Memariani Z, Mobli M, Salehi Surmaghi MH, Shams-Ardekani MR, Rahimi R. Five Pistacia species (P. vera, P. atlantica, $P$. terebinthus, $P$. khinjuk, and $P$. lentiscus): a review of their traditional uses, phytochemistry, and pharmacology. Sci World J. 2013; 2013: 219815.

7. Tohidi M, Khayami M, Nejati V, Meftahizade H. Evaluation of antibacterial activity and wound healing of Pistacia atlantica and Pistacia khinjuk. J Med Plants Res. 2011; 5(17): 43104314.

8. Saber-Tehrani M, Givianrad MH, AberoomandAzar P, Waqif-Husain S, Jafari Mohammadi SA. Chemical composition of Iran's Pistacia atlantica cold-pressed oil. J Chem. 2013: 1-6.

9. Barrero AF, Herrador MM, Arteaga JF, Akssira M, Mellouki F, Belgarrabe A and Blázquez MA. Chemical composition of the essential oils of Pistacia atlantica Desf. J Essential Oil Res. 2005; 17(1): 52-54.

10. Sharifi MS and Hazell SL. GC-MS Analysis and Antimicrobial activity of the essential oil of the trunk exudates from Pistacia atlantica kurdica. J Pharm Sci Res. 2011; 3(8): 1364-1367.

11. Farahpour MR, Mirzakhani N, Doostmohammadi J, Ebrahimzadeh M. Hydroethanolic Pistacia atlantica hulls extract improved wound healing process; evidence for mast cells infiltration, angiogenesis and RNA stability. Int J Surg. 2015; 17: 88-98.

12. Hamidi AR, Naeini AT, Tanideh N, Nazifi S. Effects of Pistacia atlantica (subsp. Mutica) oil extracts on antioxidant activities during 
experimentally induced cutaneous wound healing in rats. Vet Sci Dev. 2015; 5(1): 5672.

13. Delazar A, Reid RG, Sarker SD. GC-MS analysis of the essential oil from the oleoresin of Pistacia atlantica var. mutica. Chem Nat Compd. 2004; 40(1): 24-27.

14. Haghdoost F, Baradaran Mahdavi MM, Zandifar A, Sanei MH, Zolfaghari B, Javanmard SH. Pistacia atlantica Resin Has a Dose-Dependent Effect on Angiogenesis and Skin Burn Wound Healing in Rat. Evid Based Complement Alternat Med. 2013; 2013: 893425.

15. Taran M, Mohebali M, Esmaeli J. In vivo efficacy of gum obtained pistacia atlantica in experimental treatment of cutaneous leishmaniasis. Iran $J$ Public Health. 2010; 39(1): 36-41.

16. Tatmatsu-Rocha JC. Understanding Biomarkers Involved in Healing Delay in Diabetic Wounds. SM J Diabetes Metab. 2016; 1(1): 1005.

17. Minaiyan M, Karimi F, Ghannadi A. Antiinflammatory effect of Pistacia atlantica subsp. kurdica volatile oil and gum on acetic acidinduced acute colitis in rat. Res J Pharmacognosy. 2015; (2): 1-12.

18. Sadeghi Z, Mahmood A. Ethno-gynecological knowledge of medicinal plants used by Baluch tribes, southeast of Baluchistan, Iran. Revista Brasileira de Farmacognosia. 2014; 24(6): 706715.

19. Gourine N, Yousfi M, Bombarda I, Nadjemi B, Stocker P, Gaydou EM. Antioxidant activities and chemical composition of essential oil of Pistacia atlantica from Algeria. Ind Crops Prod. 2010; 31(2): 203-208.

20. Farhoosh R, Tavakoli J, Khodaparast MHH. Chemical composition and oxidative stability of kernel oils from two current subspecies of Pistacia atlantica in Iran. J Am Oil Chem Society. 2008; 85(8): 723-729.

21. Peksel A, Arisan I, Yanardag R. Radical scavenging and anti-acetylcholinesterase activities of aqueous extract of wild pistachio (Pistacia atlantica Desf.) leaves. Food Sci Biotechnol. 2013; 22(2): 515-522.
22. Nissen NN, Polverini PJ, Koch AE, Volin MV, Gamelli RL, DiPietro LA. Vascular endothelial growth factor mediates angiogenic activity during the proliferative phase of wound healing. Am J Pathol. 1998; 152(6): 1445-1452.

23. Schnider SL, Kohn RR. Effects of age and diabetes mellitus on the solubility and nonenzymatic glucosylation of human skin collagen. J Clin Invest. 1981; 67(6): 1630-1635.

24. Hashemnia M, Nikousefat Z, Yazdani-Rostam M. Antidiabetic effect of Pistacia atlantica and Amygdalus scoparia in streptozotocin-induced diabetic mice. Comp Clin Pathol. 2015; 24(6): 1301-1306.

25. Upadhyay NK, Kumar R, Mandotra SK, Meena RN, Siddiqui MS, Sawhney RC, Gupta A. Safety and healing efficacy of Sea buckthorn (Hippophae rhamnoides L.) seed oil on burn wounds in rats. Food Chem Toxicol. 2009; 47(6): 1146-1153.

26. Rezaie M, Farhoosh R, Sharif A, Asili J, Iranshahi M. Chemical composition, antioxidant and antibacterial properties of Bene (Pistacia atlantica subsp. mutica) hull essential oil. J Food Sci Technol. 2015; 52(10): 6784-6790.

27. Kasabri V, Abu-Dahab R, Afifi FU, Naffa R, Majdalawi L. Modulation of pancreatic MIN6 insulin secretion and proliferation and extrapancreatic glucose absorption with Achillea santolina, Eryngium creticum and Pistacia atlantica extracts: in vitro evaluation. $J$ Exp Integr Med. 2012; 2(3): 245-254.

28. Galiano RD, Tepper OM, Pelo CR, Bhatt KA, Callaghan $M$, Bastidas $N$, Bunting $S$, Steinmetz HG, Gurtner GC. Topical vascular endothelial growth factor accelerates diabetic wound healing through increased angiogenesis and by mobilizing and recruiting bone marrowderived cells. Am J Pathol. 2004; 164(6): 19351947.

29. Ilango K, Chitra V. Wound healing and antioxidant activities of the fruit pulp of Limonia acidissima Linn (Rutaceae) in rats. Trop $J$ Pharm Res. 2010; 9(3): 223-230. 